\title{
STONE OPERATOR MINING FACTS - 2005
}

\section{Mining Operations}

In 2005, a total of 4,490 stone mining operations reported employment to the Mine Safety and Health Administration (MSHA). Stone mines comprised $30.6 \%$ of all mining operations.

- Mines producing the primary commodity of limestone (crushed and broken) comprised the largest number of operations ( $n=2,039 ; 45.4 \%)$.

- Stone mining operations were located in all states and territories except Delaware and North Dakota.

- Of all states, Pennsylvania had the most stone mines ( $n=379 ; 8.4 \%)$.

\section{Employees}

A total of 69,759 employees, ${ }^{1}$ corresponding to 73,650 full-time equivalent (FTE) ${ }^{2}$ employees, were reported to MSHA by stone mine operators in 2005. This was a $3.5 \%$ increase in the number of FTE stone operator employees from 2004.

- Within the mining sectors, ${ }^{3}$ stone mine operator employees accounted for $25.5 \%$ of all employee hours reported.

- Stone operator employee hours were reported for both underground (2.9\%) and surface (97.1\%) work locations. ${ }^{4}$

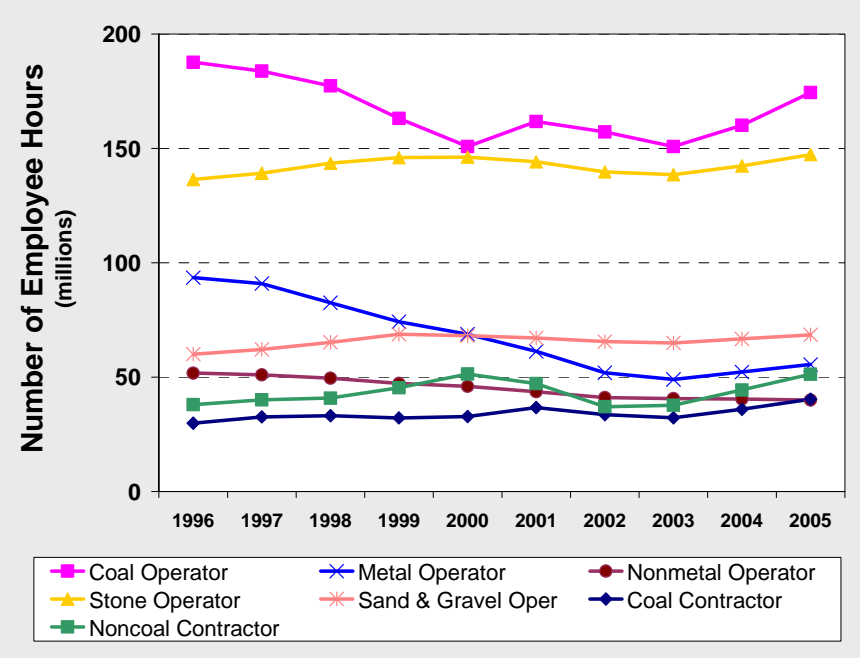

\section{Fatalities}

There were 15 occupational fatalities among stone mine operator employees in 2005.

The stone mine operator fatality rate for all work locations was 20.4 fatalities per 100,000 FTE employees.

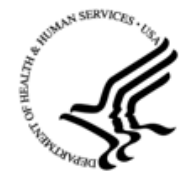

DEPARTMENT OF HEALTH AND HUMAN SERVICES

Centers for Disease Control and Prevention

National Institute for Occupational Safety and Health

September 2008

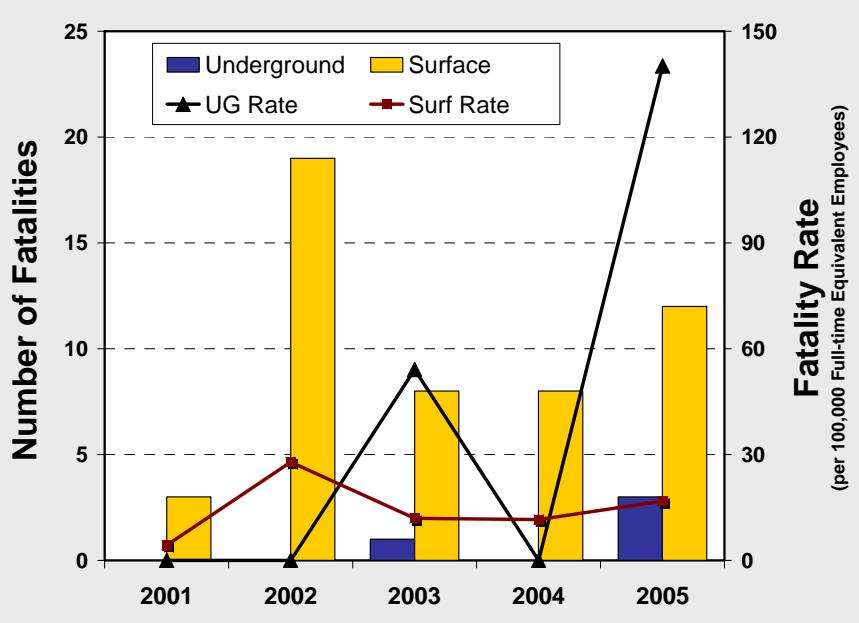

Nonfatal Lost-time Injuries

There were 2,265 nonfatal lost-time injuries (60 at underground and 2,205 at surface work locations) among stone operator employees occurring at a rate of 3.1 injuries per 100 FTE employees. A total of 99,946 days lost $^{5}$ from work resulted from these injuries.

- The nonfatal lost-time injury rate was 2.8 for underground work locations and 3.1 for surface.

- The most frequent classification of nonfatal losttime injuries for stone operator employees involved handling materials ( $\mathrm{n}=850 ; 37.5 \%)$.

- Sprains and strains were the most frequently reported nature of injury ( $n=1,033 ; 45.6 \%)$.

- The back was the most frequently reported body part $(\mathrm{n}=464 ; 20.5 \%)$ and accounted for 18,224 days lost from work.

\section{Distribution of Nonfatal Lost-time Injuries by Accident Class, 2001-2005}

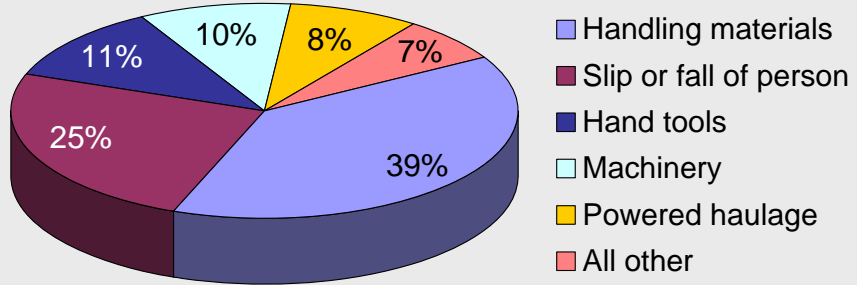

Note: "Fall of ground" includes MSHA's Accident/Injury/lllness classification for fall of face, rib, pillar, side, or highwall (from in place); fall of roof, back, or brow (from in place); and underground machinery cases when the source of injury was caving rock, coal, ore, or waste. 


\begin{tabular}{|c|c|c|c|c|c|c|}
\hline \multicolumn{7}{|c|}{ Mining Characteristics, 2005} \\
\hline $\begin{array}{l}\text { Commodity and } \\
\text { Type of Employer }\end{array}$ & $\begin{array}{l}\text { No. of } \\
\text { Mines }\end{array}$ & $\begin{array}{l}\text { No. of } \\
\text { Companies }\end{array}$ & $\begin{array}{c}\text { No. of } \\
\text { Employees }^{1}\end{array}$ & $\begin{array}{l}\text { No. of FTE } \\
\text { Employees }^{2}\end{array}$ & $\begin{array}{l}\text { Fatality } \\
\text { Rate }\end{array}$ & $\begin{array}{c}\text { Nonfatal } \\
\text { Lost-time } \\
\text { Injury Rate }\end{array}$ \\
\hline Coal Operator & 2,063 & -- & 78,281 & 87,184 & 19.5 & 3.5 \\
\hline Metal Operator & 263 & -- & 26,442 & 27,773 & 18.0 & 2.4 \\
\hline Nonmetal Operator & 739 & -- & 19,678 & 20,014 & 20.0 & 2.5 \\
\hline Stone Operator & 4,490 & -- & 69,759 & 73,650 & 20.4 & 3.1 \\
\hline Sand and Gravel Operator & 7,111 & -- & 37,705 & 34,258 & 26.3 & 2.5 \\
\hline Operator Total & 14,666 & -- & 231,865 & 242,879 & 20.6 & 3.0 \\
\hline Coal Contractor & -- & 2,503 & 32,639 & 20,136 & 24.8 & 2.7 \\
\hline Noncoal Contractor & -- & 4,297 & 46,623 & 25,590 & 7.8 & 1.6 \\
\hline Contractor Total & -- & 6,800 & 79,262 & 45,726 & 15.3 & 2.1 \\
\hline TOTAL & & & 311,127 & 288,605 & 19.8 & 2.9 \\
\hline
\end{tabular}

Fatality rates were computed per 100,000 FTE employees. Nonfatal lost-time injury rates were computed per 100 FTE employees.

Data source: Publicly released files of employment and accident/injury/illness data collected by MSHA under 30 CFR 50.

Notes: All analyses exclude office employees, except for the total number of mining operations. Analyses of fatalities exclude all individuals under 17 years of age and all individuals who were not classified as employees of a mining operator or mining contractor. Further statistical methodology is available on the NIOSH Internet [http://www.cdc.gov/niosh/mining/statistics/method.htm].

${ }^{1}$ Number of employees is the average number of persons working at individual establishments during calendar quarters of active operations.

${ }^{2}$ Full-time equivalent employees were computed using reported employee hours $(2,000$ hours = 1 FTE $)$.

${ }^{3}$ Mining sectors: coal operators, metal operators, nonmetal operators, stone operators, sand and gravel operators, coal contractors, and noncoal contractors.

${ }^{4}$ Surface work locations include surface operations at underground mines (surface shops and yards, tipple physically located at the mine site), surface operations (strip or open pit mines including associated shops and yards), dredge (mining operations conducted from a platform floating on water), other surface operations (brine pumping, etc.), independent shops and yards not associated with a specific mine, and mill or preparation plant.

${ }^{5}$ Includes actual days away from work and/or days of restricted work activity. For permanently disabling injuries only, statutory days charged by MSHA were used if they exceeded the total lost workdays.

To receive NIOSH documents or for more information about occupational safety and health topics, contact $\mathrm{NIOSH}$ at

1-800-CDC-INFO (1-800-232-4636)

1-888-232-6348 (TTY)

e-mail: cdcinfo@cdc.gov

or visit the NIOSH Web site at http://www.cdc.gov/niosh

DHHS (NIOSH) Publication No. 2008-153 